\title{
Texts, Voices and Tapes
}

\section{Mediating Poetry on the Swahili Muslim Coast in the 21st Century}

\author{
Annachiara Raia \\ African Studies Center Leiden, Leiden University, Leiden, The Netherlands \\ a.raia@hum.leidenuniv.nl
}

\begin{abstract}
In this paper, I seek to investigate the manifold relationships between traditional and contemporary, oral and written Swahili poetry-in the utendi and mashairi formsand its recitation in terms of the following considerations: how have advances in technology changed the production, transmission and reception of Swahili Islamic poetry? To what extent do writing and orality coexist in a recited text? What is the nature of performer identity formation within a "discourse network" of artists - the composer (mtungaji), reader (msomaji), and singer (mwimbaji) — who, in Goffman's words, play "participation roles" and appropriate poetry belonging to other living poets or to their own (sometimes anonymous) ancestors? In an attempt to answer these questions, I provide examples of performers and their performative craft.
\end{abstract}

\section{Keywords}

Islamic poetry - Lamu archipelago - mediation and appropriation - performing arts

Many studies have been undertaken on the world of oral performance in Africa; ${ }^{1}$ the textualization of oral epics, from their oral versions to their transcriptions; ${ }^{2}$ and on the relationship between performer(s) and oral poetry, ${ }^{3}$ as

1 See Finnegan 2012.

2 See Honko 2000; Johnson 1997; Okpweko 1979.

3 See Kaschula 1999. 
well as the technologizing and commercialization of oral and written poetry. 4 However, the relationship between poetry and its re-performances, in both written as well as spoken forms, needs further investigation. This paper draws on my field research in Kenya in 2018, where I was interested in exploring the changing mediality of Swahili poetry in utendi form, which is both a written genre and an oral one, meant to be performed. ${ }^{5}$ Most research has hitherto focused on merely one of these aspects, neglecting the other. 'Voiced Islam' vis-à-vis 'print Islam'6 is a topic that has not been adequately researched in the contemporary literary landscape of the Swahili Muslim coast. ${ }^{7}$

Differently from the many African contexts that are well known for their abiding oral-literary traditions, such as the Somali tradition, ${ }^{8}$ Swahili has a long and well-known manuscript culture that has made it one of the prime examples of written literature in an African language. It began being written down under the influence of Islam and the medium of the Arabic script. ${ }^{9}$ To the present day, poets from the Lamu archipelago, the cradle of Swahili poetry, ${ }^{10}$ still use Arabic script for composing, writing down and copying poetry. The Latin alphabet was introduced along the coast by the missionary Johann Ludwig Krapf, who opted for the alphabet after deliberating whether to adopt the Ethiopian script or the Latin one." Since at least the 18th century, as far as

$4 \quad$ See Jones 1988; Kashula 2001; Merolla 2012.

$5 \quad$ Abdulaziz 1979; Allen 1970, 1971; Harries 1953,1961; Knappert 1964, 1967; Werner 1927.

6 See Eickelmann 2003.

$7 \quad$ This paper presents the first results of research undertaken in Mombasa and on the island of Lamu in February and March 2018 to investigate the network of poets and singers currently active along the Swahili coast. The interviews and conversations presented here chiefly involve seven poets and singers based in Mombasa (Kadara), Lamu (Khadija, Mahmoud Mau and Fakhruddin), and Pate (Omar and Ridhai Sufiani), and to whom I express my warmest gratitude for having shared with me their manner of engaging with poetry. The BIGSAS and fimt symposium held at Moi University in Eldoret (20-25 March 2018) gave me the chance to share my first remarks on the topic, and I am grateful to the organizing committee for having extended me the invitation to participate. The encouraging and productive atmosphere of the Eldoret symposium would not have been so vibrant without the students, who truly contributed to creating a synergy among the group. I am also grateful to Clarissa Vierke for having shared my enthusiasm during the fieldwork and for her comments on my early remarks on the topic of Kutia sauti and on this article.

8 See Andrzejewski 2011; Banti and Giannattasio 1996; Orwin 2017.

$9 \quad$ See Gerard 1920; Knappert 1989; Piłaszewicz 1985; Vierke 2014.

10 See Dammann 1940.

11 In 1849, Johann Ludwig Krapf published his translation of the first three chapters of the Bible - the first printed document rendering Swahili in Roman script (Yahya Ali Omar and Peter J. Frankl. "A historical review of the Arabic rendering of Swahili together with 
manuscript evidence tells us, literary works in Arabic script have been passed down from generation to generation in private manuscript collections belonging to families or religious leaders. As I have shown elsewhere, the activity of copying and collecting Swahili manuscripts, which increased in the period prior to the Second World War, was largely undertaken for the sake of a Western readership, mainly for those early British and German scholars who arrived and stayed on the coast and came into close contact with reputed Islamic scholars and poets. ${ }^{1213}$ The circulation of manuscripts from across the Lamu archipelago (Amu, Pate, and Faza islands) upon British scholar John W.T. Allen's arrival on the island in the '6os reveals an interesting dynamic - one in which scribes would team with poets and poets, in turn, with the manuscript's "owner"; $; 4$ from similar manuscript cultures and networks attested along the Swahili Muslim coast from the 17th century onwards, we can now trace the shift to "voiced Islam" (al-Islam al-sawti), as aptly labelled by Dale Eickelmann. ${ }^{15}$ For this reason, in this paper I am interested in looking at the active yet newly emergent Lamuan network of composers and compositions (watungaji and tungo) through which poetry is composed and re-performed by means of new figures and voices, as well as circulated through verbatim memorization and tapes. More precisely, in this case, al-Islam al-sawti will allow us to show the ways in which contemporary Swahili Muslim poets currently engage with Swahili traditional and popular poetry in order to perform and transmit their message to future generations.

\subsection{Performance Practices}

In the following, my objects of investigation are three performative configurations ranging from the act of composing poetry to its mode of delivery: i) texts composed on behalf of someone else (henceforth captured in the expression nitungiye nami "compose for me"); ii) voiced texts (conveyed in the act of

proposals for the development of a Swahili writing system in Arabic script (based on the Swahili of Mombasa)," Journal of the Royal Asiatic Society 7.1 (1997): 56).

12 See Miehe and Vierke 2010.

13 To name just a couple, William Taylor and his work on Muyaka's poetry with Mwalimu Sikujua in Mombasa (Abdulaziz 1979), and Ernst Dammann and his work with Muhamadi Kijuma in Lamu (Miehe and Vierke 2010).

14 "The owner of a manuscript would make his or her manuscript copies (nakala) available to those who asked; in turn, the lender would either copy the manuscript him—or herself (kunakili kwa khati) or share the copying task with a professional scribe (mwandishi) or a young person. Only after the cycle was complete would the manuscript have been sold to Allen" (Raia, forthcoming).

15 See Eikelmann 2003 . 
kutia sauti "to give voice"); and iii) texts recalled by heart (kutoa kwa moyo). The three performative dimensions, accordingly, will illustrate the practices through which a text is crafted by the author-be he living or deceased, known or unknown - and yet transformed by a new performer through readings realized via oral delivery through technological mediation.

It is worth clarifying that for all the performance practices presented in the following, the departure points are always written literary pieces-either part of the classical Swahili repertoire or those drawing from everyday life and current events - that have undergone a process of appropriation and remediation. As Walter Ong puts it, "writing can never dispense with orality". 16 Indeed, this performative journey, through which the text acquires a new actualization and a new state of existence, shows how the written and spoken forms flow into each other, supporting Ruth Finnegan's claim that "the distinction between oral and written is not as clear-cut as it sometimes supposed". ${ }^{17}$ Considering the fluidity of a text and how it is made available for repetition, recreation or "copying' in other contexts", 18 I shall argue that the boundaries of authorship proper are blurred, and what matters most are the modes of communicating poetry through its appropriation and oral delivery, hence reperformances.

In the journey through the network of career performers who write down the words or give voice to them, the relationship between the poet/performer and his/her audience reveals a constant negotiation between different modes of aesthetic experience, both for the poet as well as the public. By highlighting the reasons and ways people compose and consider themselves composers or singers, this paper seeks to unravel the interplay between authors and their texts/voices, media and audiences and the blurred yet present boundaries of authorship and intellectual property. ${ }^{19}$

16 Walter Ong. Orality and Literacy: The technologizing of the world (London: Routledge, 2002): 8. Further page references are in the main text.

17 Ruth Finnegan. "How oral is oral literature?," Bulletin of the School of Oriental and African Studies 37.1: 64 .

18 Bauman and Briggs, qtd. in Barber (Karin Barber. The Anthropology of Texts, Persons and Publics: Oral and Written Culture in Africa and Beyond (Cambridge: Cambridge Univ. Press, 2007): 71. Further page references are in the main text).

19 For Somali poetry, which, as attested by Andrzjewski, used to be memorized verbatim before "it was affected by the spread of cheap portable tape recorders in the 196os and by mass literacy in the 1970s," the reciter-differently from a West African griot or a South Slavic bard- "was seldom a creative poet himself, [...] regarded merely as a channel of communication and a memory storage device and was in no way a co-author of the version he recited. [...] The custom of aiming at the verbatim rendering of the oral text had one important corollary. It was the duty of the poetry reciter to mention the name of the 
1.2.1

\section{Analytical Categories: Texts, Voices and Tapes}

The text's journey, as analysed in the following, departs from the realm of the written word and its tangible presence on handwritten paper. On the one hand, the term text itself alludes to the concept of texts as tissues of words woven or joined together (from Latin texere), and literature as the universal human activity of weaving and fabricating with words (Barber 1). This holds true for Swahili texts as well: the art and craft of composing verses is known as kutunga or kunudhumu ("to compose") and it is poetically associated and linked with the act of "threading pearls, making a necklace or rosary" 20 that is offered as a gift (zawadi) or even an amulet (hirizi). As both the verb and its metaphor hint at, nothing speaks of the practice of writing down the composition as an act per se. The poets I have met do compose their own poetry, but the written composition is just the first act of form-giving. Afterward, the text can be read aloud, (mis)interpreted, chanted or retained in one's own memory by heart.

On the other hand, the texts presented here are also explored as commodities, which as such also have social lives. ${ }^{21}$ The kitabu - a word meaning "book" in Swahili, but stemming from an Arabic root that indeed has the meaning of a bunch of unbound handwritten sheets, not previously published-thus becomes a symbolic property, belonging the author but also lent to someone else for just a set amount of time, during which that same text stirs the interpretation and imagination of a new, more or less skilled artist through his/her reading and personal nature. ${ }^{22}$ After the transformation has occurred, the kitabu returns to its poet; the borrowing is complete and the composition's

author; failure to do so was regarded as a breach of literary etiquette, and deliberate misattribution as dishonest. Any violation of this unwritten copyright law, though not a ground for litigation, could seriously harm the reputation of the reciter" (27).

20 See, for instance, Inkishafi, a melancholic poem reflecting on the glory of Pate island in the past. It was composed by Sayyid Abdallah bin Ali bin Nasir (AD1720-1820). A further example is the Utendi wa Mwana Kupona, an admonitory poem composed by Binti Msham (Bwana Mtaka's wife, AD1810-1860)—who died prematurely — to her daughter Mwana Hashima binti Sheikh (1841-1933). It is a poem that is still known by heart by many people in Lamu and Pate today. It was published in J.W.T. Allen's utendi collection.

21 Arjun Appadurai. Social Life of Things: Commodities in Cultural Perspective (West Nyack: Cambridge University Press, 1986): 3 .

22 This echoes Michael Bakhtin's and Roland Barthes's notions of texts, aptly summarized in the following quotations: "Where there is no text, there is no object of study, and no object of thought either" (Bakhtin 103); "The text you write must prove to me that it desires me. This proof exists: it is writing." (Barthes 6). 
new oral rendering is produced, affording it a new life in a new medium, a format that depended on its previous written format to be actualized and orally delivered.

Whenever poets put words together, they do so to leave a mark and, as Barber puts it, they do this orally as well as in writing (1). As I will show in my analysis, within the act of composing as well as re-performing a text orally, poets experience an encounter with the text they create or appropriate. ${ }^{23}$ The ideas and voices imbued in the words stitched together embody a message (ujumbe) having an aesthetic appeal and meant to reach and touch a precise person as well as a wider community. All the performers whom I have talked to have experienced such encounters with their poems, which they are committed to composing, which they are requested to sing, and which they long to memorize and keep alive.

\subsubsection{Voices and Voicings}

The pivotal role played by the so-called "auditory (or sonic) Islam" dates back to a long scholarly tradition. ${ }^{24}$ In the Swahili Muslim literary tradition, sound and voice, both labelled with the term sauti, play an important role in the art and craft of stringing words together. It is worth citing what Ustadh Mahmoud Ahmed Abdulkadir (more commonly called "Mahmoud Mau") from Lamu says in this respect:

Poetry is words that are written or uttered using syllables and a specific arrangement, and the poet or singer is attracted by the musicality deriving from its arrangement. A poet uses words (maneno), syllables (mizani) and rhyme (vina) to express what he wishes. [In doing so], s/he can make people happy or sad. ${ }^{25}$

Along with the three elements of maneno ("words"), mizani ("syllables"), and mpangilio ("structure"), ${ }^{26}$ Mahmoud Mau mentions a sort of sensuous and captivating power-that is, musicality (muziki) — that is created between those

23 Matthias Krings begins his introduction to "African Appropriation" by referring to his encounter with a song; as he puts it, he was "touched by the powerful force of this spontaneous live performance and deeply impressed by the professionalism of the choir" (1).

24 al-Faruqi 1985; During 1997.

25 "Ushairi ni maneno yalio andikwa au kusemwa kwa mizani na mpangiliyo maalum-na msomaji au msikilizaji huathirika kwa maneno hayo kwa sababu ya muziki unao tokana na mpangilio wake-mshairi hutumiya maneno na mizani na vina kueleza analotaka aweza akasikitisha watu au akawafurahisha" (Mahmoud Mau, October 2017).

26 In his rules for composing poems (Sheria za Kutunga Mashairi, 1979), Amri Abedi talks of 
words, the poet who has strung them together and the reciter who gives voice to them. This also recalls the "sensitivity to sounds and meanings carefully crafted"27 in the poetry of Abdilatif Abdalla, who once said in an interview, "Poetry is not only about meaning, but also about sounds. That is what makes poetry."28 Poetry appears as a composition of sound able to enact an aesthetic experience. The re-mediations presented in the following will shed light on the particular relationship between moral/religious poetic texts-meant for entertainment as well as instruction-and voices.

In Swahili, the performance practice of "giving voice" (kutia sauti) embodies an activity closer to 'chanted reading' than singing. ${ }^{29}$ Indeed, unlike in much singing, the use of musical accompaniment is not allowed in the practice of kutia sauti, and the performer who gives voice to a text is called a msomaji ("reader") rather than a mwimbaji ("singer"). ${ }^{30}$

The power of giving voice to a text is precisely that voices are "material embodiments of social ideology and experience." ${ }^{31}$ As Eisenberg also attests,

the concept of "being sufficient" (kutosheleza), in the sense that every stanza (ubeti) is a complete whole - prosodically, syntactically and semantically (19).

27 Vierke, Clarissa. “'What Is There In My Speaking': Re-Explorations of Language in Abdilatif Abdalla's Anthology of Prison Poetry, Sauti Ya Dhiki," RAL 488.1 (2017):135-157.

28 Interview with Abdalla, qtd. in Vierke (Vierke, Clarissa. "'What Is There In My Speaking': Re-Explorations of Language in Abdilatif Abdalla's Anthology of Prison Poetry, Sauti Ya Dhiki," RAL 488.1 (2017):135-157). As concerns the sound, it is indeed also worth citing what Kai Kresse said about his first experience listening to the Wasiya wa Mabanati in Mombasa: "Trying to listen sound quality of the recording but also because I lacked some vocabulary; ... Yet what was clearly apparent to me was how captivating indeed this poem was for the listeners here, and this seemed to confirm my own initial reaction to its sound, as I was drawn in by the sad, yet dignified and measured voice of the reciter" (47).

29 This practice is similar to what Andrzjewski has described in the Somali context: "There was no musical accompaniment of any kind and the uniformity of the melody to which each line was chanted created an impression of detachment and distance on the part of the reciter, who also refrained from gesticulation or mimetic facial movements" (27).

30 As attested by Sheik Nabahany (see Vierke 23-24), one can scan (kukangaya) a Swahili utendi composition. Genres such as utendi, as well as utumbuizo, and ukawafi, are all meant to be chanted rather than sung. This kind of practice should not be confused with the recitation of the Qur'ān, which is different still, and called kughani. However, according to the young expert Fakruddin, one can also scan short poems or passages of the Qur'ān; this would imply a very slow chanting process, also causing a change of melody. In this respect, it is worth highlighting what Vierke has concluded from her stylistic analysis of the poetics of the utendi: "Chanting is different from singing in that it follows 'normal intonation' more closely, allowing more variation with respect to rhythm and melody than a song would do. A song imposes its own rhythm, and the melody can override speech intonation and accentuation of the text" (Vierke 23-24). 
"The singing voice can serve as a powerful technology of public reflexivity". ${ }^{32}$ More precisely, the public reflexivity that comes to the surface in this paper speaks of those new forms of Islamic artistic entertainment that are licit and tailored to younger generations ${ }^{33}$ and have become the engine of religious sociability. ${ }^{34}$ A poet like Mahmoud Mau, who is also an imam on Lamu island, imbues his verses with religious and moral teachings that he wishes to impart to the community, and he acknowledges the power of media through which his own compositions may reach a wider audience more quickly. Along the same lines, old tendi of the past, used for expressing admonishments, as in the case of Mwana Kupona, are considered to be guidelines as well as talismans to keep in own's heart and mind, and this is the reason why talented poets, gifted with awe-inspiring voices, like Abdallah el-Shatry from Mombasa or Bi Ridhai Sufiani from Pate, continue reciting aloud both classic as well as popular Swahili compositions by heart.

\subsubsection{Tapes and Tape Markets}

These voiced texts have become increasingly popular in the Islamic milieu of the Swahili Muslim public; new technologies, first audio cassettes, ${ }^{35}$ then CD s ${ }^{36}$ and later the Internet enabled these poems to circulate more widely. Like the loudspeakers that have become the vehicle for more widely disseminating the call to prayer in Nigeria, ${ }^{37}$ voice recorders have enabled traditional as well as contemporary Swahili Muslim poetry to reverberate in various domestic contexts as well as in the streets or at tape markets in Eastern Africa. These audio recordings have in turn created new audiences, in Hirschkind's terms "counterpublics", ${ }^{38}$ which entail or coexist with the performative aspects of voice and voicing texts. Audio recorders, which I will comment on in the following, could be easily labelled as 'halal fun' (Jouili and Moors 980) and considered as forms

guage to the Language of Song," in: A Companion to Linguistic Anthropology, ed. by Duranti Alessandro (Malden, MA: Blackwell, 2007): 332.

Andrew J. Eisenberg. "The Swahili Art of Indian Taarab: A Poetics of Vocality and Ethnicity on the Kenyan Coast," Comparative Studies of South Asia, Africa and the Middle East 37.2 (2017): 337. Further page references are in the main text.

33 Deeb and Harb 2007.

34 Jeanette S. Jouili and Annelies Moors. "Islamic Sounds and the Politics of Listening," Anthropological Quarterly 87.4 (Fall 2014): 980. Further page references are in the main text.

35 Amidu 199o; Hirschkind 2006.

$36 \quad$ Kresse 2011; see also Raia forthcoming.

37 Larkin 2014.

38 Charles Hirschkind. The Ethical SoundScape: Cassette Sermons and Islamic Counterpublics (New York: Columbia University Press, 2006): 107. 
of licit entertainment and consumption. This also holds true for the video recordings - both professional and amateur ones - that are broadcast on YouTube nowadays. To cite just a few examples, the Swahili qașida Mwenda Madina ni nani ("Who is the Person Going to Madina?"), composed by Muhammad Habebu, was recorded in a performance by Arash Ajamy Rashid Muhammad in 2016 and made available to the vast Swahili Muslim coastal community. The official video recording has also lent itself to adaptations: Mwenda Madina ni nani, a poem in which the lyrical I expresses his longing to visit holy Medina, is indeed performed during maulidi celebrations in male as well as in female contexts. ${ }^{39}$

As will be shown in the following, the performance practices through which poems are rendered in the world of sound via audio recorders and memory storage devices can take place overtly, for mass consumption and commercialization (as in the case of Bwana Fakruddin and the stacks of CDs for sale), or privately (as in the case of Bi Ridhai and her indoor recitations). ${ }^{40}$

The Reasons and Ways Poets Compose: Seven Artists' Arts and Crafts

Most of the composers with whom I have spoken claim to have received the art of composing poetry (fani ya ushairi) by inheritance (urithi). While some compose poetry by profession, others do it as a secondary activity and not as a remunerated job; whereas some make the effort to take part in poetry competitions and their fame is well known among the islanders, others-particularly woman-nurture a very quiet and intimate relationship with poetry: they hardly show up in public, nor do they regularly attend poetry contests. Nevertheless, one general belief shared by all seven artists among the composers and singers interviewed concerns the talent (kipawa) that they strongly claim

39 When I took part in the Maulidi preparations in Pate, I was impressed by the audience's warm enthusiasm on hearing the artist's performance of Mwenye Madina ni nani. Many stood up and slowly started trying to find their way through the seated audience in order to approach the singer and tip her. In Mombasa, the qașida has been re-performed by her brother Nassir with the music accompaniment of matari ("tambourines") —also used in taarab music - a video recording of which has been made available on social networks as well as on YouTube.

40 Furthermore, the ways - private or public —in which poets engage with their own compositions and/or renderings also hint at possible issues of gender performativity, which however goes beyond the scope of this paper and demands further research. 
to have received from their family. ${ }^{41}$ In the following, I will introduce the composers and their artistry.

Ustadh Mahmoud Ahmed Abdulkadir, commonly known as Ustadh Mau, is an imam, teacher and poet from Lamu. Mahmoud Mau's father, Ahmed Abdulkadir Nasrouddin - the last-born son of Mau's grandfather Abdulkadir Abdul Latif and his grandmother Hadidja - was a poet himself. Mahmoud Mau still has a poem that his father composed especially for him, Hapo Zamani za Jana ("Once Upon a Time"); the poem features the same tone and theme of paternal advice that one finds later on in the poem that Mau composed for his son Abud in 200o, Haki za Watoto ("The Children's Rights"), which addresses all the parents in the community. ${ }^{42}$ Mahmoud Mau started reading his father's poetry when he was a young boy, an activity that made him start appreciating and composing poetry on his own. Another factor that helped to train him as a poet was the madrasa that he attended for nine years, where he learned how to chant and compose qașid $a^{43}$ to be recited at celebrations of the prophet's birthday (maulidi).

Beyond the Friday sermons that he writes weekly, Mahmoud Mau also composes Swahili poems in Arabic script, which he claims is easier and simpler for him. He writes both short and long poems (mashairi mafupi and mashairi marefu or tendi) and, for quite a number of them, after having penned down the text, Mahmoud Mau felt the need to have them recited and recorded on tapes or DVD s that were then made available for sale at local handicraft shops in Lamu and Mombasa. Even nowadays, recordings of his poems-such as Hakiza Watoto ("Childrens' rights"), Wasiyaya Mabanati ("Advice to the Ladies"), Ramani ya Maisha ya Ndowa ("The Map of a Marriage Life"), Uzinduzi ("Inaug-

41 Among the Xhosa iimbongi, praises, i.e. izibongo, are considered an isiphiwe "gift", "which manifests in the chosen few who develop this art form professionally in order to gain wide recognition" (Kaschula 58). However, as Kashula puts it in his comparative research on iimbongi and griots (1999), "contrary to the view of developing this art form within an individual who has the gift of praising, Diop (1995a: 34) points out that among griots, this is an inherited position. Okpewho (1988: 7) differs slightly and acknowledges that 'the training and preparation of the free-lance poet are not as formal or regulated as those of the poet in the more restricted context.' This implies less rigidity in the way griots are tutored and learn their profession than that proposed by Diop" (Kaschula 58).

42 Like the Waisya wa Mabanati, the Haki za Watoto was sung by Karama and is available from many shops in Lamu and Mombasa. A copy provided by Mahmoud Mau during his first visit to Bayreuth, Germany is now also kept at the DEvA archive at the University of Bayreuth.

43 The qașida is an Arabic verse form that flourished in pre-Islamic era and has travelled throughout Arabic, Persian and Turkish literature. On the influence of qașida on the development of Swahili rhyme and verse forms, see Abdulaziz (411-428). 
uration"), Mwangaza ("The Light"), and Utenzi wa Kikuba ("The Poem about the Kikuba")-are stacked up in boxes in the small stalls of the al-Hussein Shop in the Mkomani area of Lamu and at the Mbwana Radio Station in Kibokoni, Mombasa. ${ }^{44}$

Why has Mahmoud Mau decided to have his poetry recorded, rather than, for instance, collecting his more than 9o poems in an anthology and publishing it? Mahmoud Mau claims that the society he belongs to does not nurture a proper 'reading culture' as understood in the West; his community is instead eager to listen and to memorize by heart: zaidi tunapendelea kusikiliza kuliko kusoma ("We prefer listening over reading"). ${ }^{45}$ This is in line with the fact that poetry contests have exploded in popularity in Lamu, where, on the occasion of the Lamu Cultural Festival, poets perform their works before a jury who will evaluate their artistry and award a winner. ${ }^{46}$ In Lamu, as part of the jury of the poetry competition, Mahmoud Mau has seen and evaluated many poets performing their works and competing on stage at the festival. ${ }^{47} \mathrm{He}$ recalls, for instance, the name of Bi Khadija Ahmed Ahmed, daughter of Ahmed Ahmed Badawy, the founder of the Riyadha Mosque in Lamu.

44 Each composition is recorded on tape or CD (santuri) and sold for 10o Kenyan shillings (KES), or \$ 0.99. Therefore, what should be "priceless"—-since, after all, it's an art rooted in your genes-is nevertheless assigned a price. Still, the value of each recording is not fixed; it can change, increasing in those cases where the $\mathrm{CD}$ includes more than one poem. For instance, a CD of 300 short poems written by Ahmed Nassir from Mombasa and chanted by his brother Juma Bhalo costs 3 Oo KEs: one CD containing 300 works will thus cost more than a CD containing just a single composition.

45 Interview with Mahmoud Mau on the benefits of education ("Faida ya Elimu," o:o9:35o:o9:43; https://www.youtube.com/watch?v=518LhET8GoE, accessed September 26, 2018). This concept, which requires further research, echoes what Charles Hirschkind describes in a chapter titled "The Ethics of Listening" (2006).

46 In a similar way, in fact, the reading culture of Italy is no longer confined to the written word. In contemporary Italy, where more verses are written down than recited aloud, the so-called 'poetry slam' ('slam poetry' in English)—launched by Lello Voce in 2011-has been popularized, and has become a social occasion on which established and aspiring poets meet each other and compete before a jury. As remarked by the journalist Fabio Chiusi in L'Espresso, the poetry slam initiative "has hybridized the world of verses with that of exhibition and the qualities of the poet with those of the performer, but has also opened it up to sections of the population that would otherwise never come into contact with this world" (ibridando il mondo dei versi con quello dello spettacolo, le qualità del poeta con quelle del performer, ma anche aprendolo a fasce della popolazione che altrimenti non vi entrerebbero in contatto; http://espresso.repubblica.it/visioni/cultura/2017/01/31/news/ poesia-1.294411). Analysing the global phenomenon of slam poetry, which has spread throughout Europe as well as Africa, is another topic that requires further research beyond the scope of this article.

47 For further criticism on competitive music performance in Kenya, see Gunderson and Barz. 
Bi Khadija Ahmed Ahmed claims that composing poetry is a talent she inherited from her father, Ahmed Ahmed Badawy. She rarely likes to participate in public poetry contests, nor did she agree to be photographed or recorded during our conversation. Nevertheless, her participation in the poetry competition shows how much these social and cultural events are able to stimulate and encourage poets whose works would not otherwise be known to everybody on the island. In her daily life, she mainly composes poems on commission-a practice whose nuances I will comment on in the following section-and, as she says, she started doing so for mtezo mtezo ("fun"), but it then turned into a real kazi ("job"). Differently indeed from Mahmoud Mau, who is also regularly asked to compose poems on behalf of other people but doesn't receive any remuneration, Bi Khadija earns a little extra money from her compositions. Although the craft has thus become a job for her, it is something that she undertakes privately, at her home.

On Pate island, I also came to meet a very inspiring and virtuosic poet from the Sufiani family of Pate. Born of a mother who unfortunately died after giving birth, Ridhai and Omar Sufiani are two siblings who were raised by their grandmother, Fatma Athman. Fatma Athman, who passed away in 2003 at the age of 9o, was a famous poet from Pate, from whom Omar and Ridhai learned how to compose poetry. ${ }^{48}$ Bi Ridhai started composing poetry when she was 15 , and as she tells us, she was "stealing" from her grandmother; while she was composing, her grandmother listened to her and corrected her mistakes. ${ }^{49}$ In her description of "stealing" - i.e., the art-from her grandmother (kumwibia nyanyangu), we can already detect the idea of acquiring a craft or inheriting a talent through re-practicing and re-performing it on one's own.

Unlike his sister, Omari composed his first poem only in 20oo. Before that time, he had acquired a passive knowledge of poetry by listening to his grandmother after school, and also thanks to his wife, Ummi. ${ }^{50}$ Attending schoolnot until the fourth year, in Ridhai's case - also allowed him to learn the rules of composing poetry. His first well-known poem was Kimataifa ("International"), which was published in a newspaper as the winner of a poetry competition among secondary schools and universities. A poem titled AIDS earned him first place in the Coast Province (Mombasa, Kwale, Taveta, Tanariva and Lamu) at the Lamu Cultural Festival poetry competition in 2003.

48 Unlike their grandmother, their father was a farmer (Ridhai Sufiani, personal communication; Pate, March 2018).

49 Nilikua nikimuiba nyanyangu kisha na mimi nikichunga akinisikiliza. Penye kosa akinirekibisha (Bi Ridhai Sufiani, personal communication; Pate, March 2018).

5o His parents-in-law, Farouk Mohammed Farouk and Zuena Mohammed, belong to a famous family of poets as well. 
If the Swahili saying claims nyota njema huonekana alfajiri ("a good star is visible at dawn"), in contrast to Omar Sufiani, Bi Ridhai hides a real talent: beyond her skill in composing, which she acquired from her grandmother without any books, she also has a beautiful timbre, with which she has read several classical Swahili utendi compositions in the past, the majority of which she knows entirely by heart. She has given voice to them by making recordings (kusajili or also kurekodia, the latter a loan from English "to record"). As with the practice of writing poetry on commission, I will also focus on the dynamics of recording poetry in the following section.

Aside from Bi Ridhai of Pate, among those artists who are renowned for their practice of "giving voice" to texts, I will focus particularly on the personalities of two singers (waimbaji) whose activities are connected with the verses of Mahmoud Mau. Just as the famous ta'arab singer Juma Bhalo of Mombasa functioned as the "mouth" of the texts written by his "brain" - that is, his cousin Ahmed Nassir (Eisenberg 345) — we can assume the same in the case of Mahmoud Mau and the singers he has collaborated with so far: Muhamad Abdalla Bakathir (henceforth Kadara) and Abubakar Mukhsin Sayyeid Ali (henceforth Fakruddin). Both singers have re-performed poems written by Mahmoud Mau: Kadara has, for instance, given voice to Mau's Wasiya wa Mabanati ("Advice to the Ladies"), Fakhruddin to Mahmoud Mau's Ramani ya Maisha ya Ndowa ("Map for Married Life").

The singer/recording artist Kadara was born in Lamu, but now lives in Mombasa. His father, Abdalla Muhammad Bakathir, was a renowned poet and businessman in Lamu. Kadara himself is mainly a singer, but he also composes poems on commission. He regularly visits and spends his afternoons at the Mbwana Radio Service in Kibokoni, Mombasa. Bwana Fakhruddin is a younger mwimbaji, born in Lamu in 1984, and his father, Muhsin Sayyid Ali Badawy, was a famous singer of qașida and religious songs. Bwana Fakruddin studied in Egypt; he currently teaches at madrasa and is enrolled at Pwani University. He deems himself a singer more than a composer, and he considers it a talent (kipawa) coming from God as well as from his time at madrasa, where he was taught the recitation of qașida.

It should not be regarded a coincidence that the Qur'annic schools that some of the artists attended have made an impact on their becoming skilled composers or singers. Indeed, the teaching of the Qur'annic texts par excellence, such as qașid $a$ and the Qur'an, have allowed two of the artists we have seen so farthe composer Mahmoud Mau and the singer Fakruddin — to begin training in their craft. ${ }^{51}$

$5^{1}$ This is the same in the case of ta'arab singers such as Siti binti Saad or Juma Bhalo, whose 
To give a text an Author is to impose a limit on that text, to furnish it with a final signified, to close the writing. BARTHES 147

the printed words alone represent only a shadow of the full actualization of the poem as an aesthetic experience for poet and audience. FINNEGAN 5

This paper gives some accounts of the process of composition of a literary piece, from its tangible existence on a piece of paper to its further transmission through the medium of actual delivery or digital recording.

Tailoring Poetry on Commission: Nitungiye nami (“Compose for Me Too")

Composing a poem on request raises questions concerning the relationship between the person asking for a poem (the customer) and the poet/author. What does "requesting" a poem mean and who is the real author: the poet who writes or the person suggesting what to say in the poem? What stirs the people to retain a poet so that their message might arrive properly with the recipient? We will see how, when someone submits his thoughts to a poet, the latter can translate those ideas into powerful words.

3. Leo tumetoka kote vigelegele ngomani

Wageni wetu wa Pate na Mombasa na Kikomani

Na wengine wetu wote sisahau wa ng'ombeni ni cha Pate nisikieni dhuriya

... 8. Leo ni hapa dadangu sio natafutu sifa
Today we have come from everywhere, dancing and ululating

Our guests from Pate and Mombasa and Kikomani

All our people, not forgetting the other side

The Pate people should listen to me and participate

Today is my sister's day, I am not here looking for praise

"vocal talent" emerged from the practice of tajwid, the science of teaching pupils how to recite the Qur'ān (Eisenberg 344). 
Nijile kuombea Mungu ewe dadangu latifa

Iwe ya maisha pingu mupendame hadi kufa

Na kila lenye matungu lisiweze karibia

... 19. Naiogopa bahari nachezea vidimbwini

Hapa mwisho wa safari nimefika ukingoni

Hulia kimfikiri Fatuma wa Athmani

Alonifunza shari amrehemu Jaliya
May I pray to God the Merciful on behalf of my sister

May she stay married till her death

And may no sort of bitterness approach her

I am afraid of the sea, I play in pits with little water

Here at the end of my journey, I have arrived at the hall

[She] who weeps as I am thinking of her is Fatuma wa Athmani

[While she] who taught me poetry, may God have mercy upon her

The above poem is an example of a text written by Omar Sufiani from Pate for the wedding of his sister Fatuma. In the beginning, the poet refers to the important day that has brought everyone together to pray for the couple; in the course of the poem, he wishes the woman a life without bitterness; and in the second-to-last stanza, he cites the name of Fatuma wa Athmani, for whom the poem was composed. After invoking her name, Omar pays tribute to his grandmother, who taught him how to compose poetry, as if he is indicating the family inheritance and showing gratefulness for it. The above case is just one example from the many poems that poets write on commission for others every day. This is an exceptional case, however, since the composer knows the person to whom the poem is addressed. In other contexts, as I shall show below, the mtungaji is asked to write on commission for somebody whom s/he does not know.

Generally, using the expression "nitungiye nami", a Lamuan "customer" may knock at a poet's door and ask the poet to compose a poem for him or her. The person who asks for it is by no means the one to whom the poem is dedicated. The real recipient of a poem on commission usually does not know in advance that there is a "message" for her/him. The customer-who is commonly a close relative or friend of the would-be recipient of the composition-thus plays the role of mediator between the recipient and the composer. In Lamu, Bi Khadija Ahmed Ahmed, who welcomed me into her home in the Riyadha area, was asked by a friend of hers to compose a poem on commission. Bi Khadija stood up and took from her cupboard a notebook with a black leather cover and wrote down the following notes: she asked the person requesting the poem 
when she would need the poem to be ready; the name of the poem's recipient; and the occasion for which it was intended. Then she asked some information about the receiver of this poem: "Why is she important to you? What do you want to wish or to say to her?" The poem was ordered for the wedding of the customer best friend's daughter, from Shela. In fact, the customer's thoughts were addressed to her friend more than to her friend's daughter. She explained to Bi Khadija her deep friendship with the bride's mother and the woman's importance to her by providing her with inspirational quotes, such as "She is like my best friend; we get along very well and we talk to each other every week." 52

The customer, in revealing such personal details to Bi Khadija, did not intend to expose the private confessions of the women tout court, but to allow the poet to understand the emotions and rationale behind her thoughts, which she longed to see transferred into a powerful, attention-worthy verse form. In so doing, the customer requesting a poem on commission becomes a "hidden cocomposer" of that text, while the composer's task is to arrange those thoughts and feelings - like pearls on a necklace — into words bearing syllables (mizani) and rhyme (kina) as well as musicality (muziki), ones that are remarkable to the point of creating emotional involvement.

This is exactly in accord with how Ustadh Mahmoud Mau-who also writes short poems (masharimafupi) for the people who regularly knock at his library door-describes the practice of writing poems on commission. Ustadh Mahmoud Mau acknowledges that the community ( jamii) needs people who can convey the message (ujumbe) that is in one's heart and mind into a better form (kwa ndiya nzuri zaidi), namely poetry. ${ }^{53}$ When he writes on commission, he is writing through the lens of the other person: "He (the poet) composes on behalf of a person or other people, and in this case the poet will have to make an effort to put himself into the situation of the person on whose behalf he is speaking." ${ }^{54}$ The inspirational details that the customer gives to Bi Khadija, the real composer, are certainly helpful since, as Bi Khadija herself says, "If you don't know the person to whom the poem is addressed, nor do you have calm

52 Yeye ni kama bui wangu, twaelewana vizuri na twawasiliana kila juma, kila juma kwa shida tofauti (the customer's reported speech, Riyadha, Lamu, February 26, 2018).

53 Jamii huwa inawahitaji watu hawa kwasababu wanawasaidiya katika kuwasilisha ujumbe wao kwa ndiya nzuri Zaidi (Ustadh Mahmoud Mau, personal communication, Bayreuth, 2017).

54 Anatunga kwa niyaba ya mtu au watu wangine na katika hali hii ya pili inambidi mshairi ajiweke katika mazingira ya ule mtu ambao anatunga kwa niyaba yake (Ustadh Mahmoud Mau, personal communication, Bayreuth, 2017). 
around you, the composition of a poem will take you longer in comparison to the activity of writing for a person whom you already know." 55

Returning to Omar Sufiani's first poem, written in 2000, this work was also commissioned by a friend who asked the poet to compose a poem for his sweetheart; thus Omar wrote a love poem for his friend's girlfriend. The poem was then "sent by the lover to his sweetheart, like a letter to her" (alitumia kama barua kwa mpenziwe) containing a love message in verse form. ${ }^{56}$

What emerges particularly from the abovementioned case studies is that, when the poems are written on commission on behalf of somebody else, the name of the composer does not appear in the composition; on the contrary, what is mentioned in the opening stanzas is the name of the recipient to whom the poem is dedicated. Neither Omar Sufiani nor Ustadh Mahmoud Mau earn anything from writing poetry on commission. Ustadh Mahmoud Mau does not care to be either the patron or owner of the composition; his involvement with the poem finishes at exactly the moment when his creation of the artwork, the transformation of someone else's thoughts into verse form, is completed. Once the poet hands the commissioned poem over to the person who ordered it, he no longer feels linked to that piece of paper, which has instead been appropriated by somebody else, the new and real recipient of that symbolic message. Why do they do it then, if not with the aim of earning a living, as in the case of Bi Khadija? As Omar Sufiani says, his writing on commission is a chance to improve his talent; it is like training in order to improve his own performances when composing poetry for a specific purpose.

Poetry on commission is thus revealed to be a craft as well as a service. The symbolic commodity of the verses written down on those loose sheets will pass from one hand to another, containing a poem that seems to belong to everyone and yet to no one at the same time; what matters is that the poetry might resonate powerfully with its audience.

Simultaneously, artists, whether they consider themselves composers (like Ustadh Mahmoud Mau, Omar Sufiani or Khadija) or singers (like Bwana Fak-

55 Ikiwa akili itulia na ikiwa wamjua na wamfahamu yule mtu itakuwa rahisi zaidi kumsifu na kutunga shairi kwa ajili yake (Bi Khadija, personal communication, Riyadha, Lamu, February 26,2018 ).

$5^{6}$ This can clearly be related to the conception of poetry expressed in a conversation between Pablo Neruda and Massimo Troisi (Mario) in the film The Postman (1994): "Poetry does not belong to the writer, but to the one who needs it." After all, didn't the postman appropriate a love poem — that Neruda had written for his own lover — to deliver it orally to the woman with whom he himself was in love? 
ruddin), all retain a certain freedom in readapting what previously-intellectually or otherwise-belonged to someone else. In the context of southern Africa, Vail and White point out, "it is not the poet that is licensed by literary convention, it is the poem". ${ }^{57}$ It is thus not surprising that also in the Swahili Muslim context of East Africa, once the poem written on commission arrives in the hands of the recipient, the reader might change a word, use the wrong intonation or even skip some lines. It is worth noting here the words of the English poet Adrian Mitchell, who used to say, "I change poems when I read them aloud." 58 This is indeed an aspect not only of poetic performance, but also one involved in the performance practice of recording written compositions by "giving voice" to them while reading a text or delivering it by heart, as will be investigated in the following.

\subsection{Kutia sauti, "Giving Voice"}

A first consideration that must be made is that a good composer is not necessarily a good singer, but nevertheless may harbor the desire to have his own poems recorded—kusajili-or even re-recorded and offered for sale. The process of kutia sauti "giving voice" is a practice in which the poet-if still living and known-is separated from his own written text and a new skilled craftsman, generally considered the reader or the singer (msomaji or mwimbaji), encounters that same text and will appropriate it by converting it into a new, voiced form. As the singer Bwana Fakhruddin maintains, "to give voice means to give a melody." ${ }^{9}$ He continues, "If you listen to a song, each song has its melody. This is the same with poems. [You should] put different melodies so that they might captivate people, [such as] a melody that makes one sad-and thus people start crying — or a melody that makes one feel happy."60 Thus, just as musicality in poetry is the result of a captivating relation between words and the one who strings them together, "giving melody" to a poem also lends it a powerful and emphatic value. Such vocality attracts and touches the audience, perhaps

57 Leroy Vail and Landeg White. Power and the Praise Poem. Southern African Voices in History (London: James Currey, 1991): 56 .

$5^{8}$ Horovitz, qtd. after Finnegan (Ruth Finnegan. "How oral is oral literature?," Bulletin of the School of Oriental and African Studies 37.1 (1974): 59).

59 Kutia sauti ni kutia maadhi (Bwana Fakruddin, personal communication; Lamu, February 2018).

6o Ukisikiliza nyimbo, kila nyimbo ana maadhiyake. Na mashairivile vile. Kutia maadhi tofauti ili iweze kuwavutia watu, maadhi ya kusikitisha (watu waanza kulia) maadhi anasaidia au maadhi ya kufurahisha. (ibid.) 
even more than the verbal artistry imbued in verses may touch readers; vocality becomes an aesthetic experience that makes the poem come to life. Secondly, while in composing, every poet should have a talent (kipawa) and know how to arrange words, rhymes and syllables (maneno, mizani, and vina) well in a line, by imbuing a written text with musicality (muziki), the singer is adding additional "beads and pearls" that are endowed by the special melody (maadhi maalum) and captivating voice (sauti nzuri). ${ }^{61}$

Ustadh Mahmoud Mau does not consider himself a good singer. One of his works that has been recorded multiple times is the Wasiya wa Mabanati ("Advice to the Young Ladies"), first recorded by Muhammad Abdalla Kadara in 1975, then finely performed by Abdallah el-Shatry and recently by Ridhai Sufiani in $2018 .{ }^{62}$ In line with a kind of rivalry between print and voiced Islam, the voices of these abovementioned singers enchant listeners to the point that the voiced versions of the poem will make the text more popular than in its written form, and make the singer just as famous as-if not more famous than-the composer of the text. The poem Wasiya wa Mabanati has had an incredible resonance not only on Lamu island, but also in Mombasa thanks to the voice of Abdallah el-Shatry, a talented singer who chanted it and then died prematurely. ${ }^{63}$ Kai Kresse refers to precisely this vocal power as a "meaningful orality". ${ }^{64}$ The popularity of the voiced Wasiya version, in any case, does not contradict the intentions of its composer, Ustadh Mahmoud Mau, who acknowledges the merits of el-Shatry's recorded rendering, claiming that "the poem has made many people sad, but at the same time people like to listen to it since it is a story to be told and to relate to things that some people have

61 The words in italics are Usatdh Mahmoud Mau's own words, from a conversation with him in October 2017.

62 As Usatdh Mahmoud Mau has explained to me, the request to have the Wasiya recorded was not made by himself, but rather by a man named Swaleh, who wanted his children to listen to it and thus asked Kadara to record it. Afterwards, this recording began to be shared and copied among the community. The second singer, Abdallah el-Shatry, was also not contacted by Mau himself, but rather by the owner of a CD kiosk, Ghalib Muhadhari, who asked el-Shatry to sing it in his voice. In the cases of Mau's other poems, such as the Ramani, Mukadirat and Haki za Watoto, it was Mau himself who asked the singer(s) to give voice to them.

63 Abdallah el-Shatry's recording of Wasiya wa Mabanti is also available at https://soundclou d.com/search?q=wasiya\%2owa\%2omabanati. The composer is named and called $m s h a$ hiri ("the poet"), whereas Abdallah el-Shatry, who has given voice to the text, is referred to as msomaji ("the reader").

64 Kresse, Kai. "Enduring Relevance Samples of oral poetry on the Swahili coast," Wasafiri $26.2(2011): 47$. 


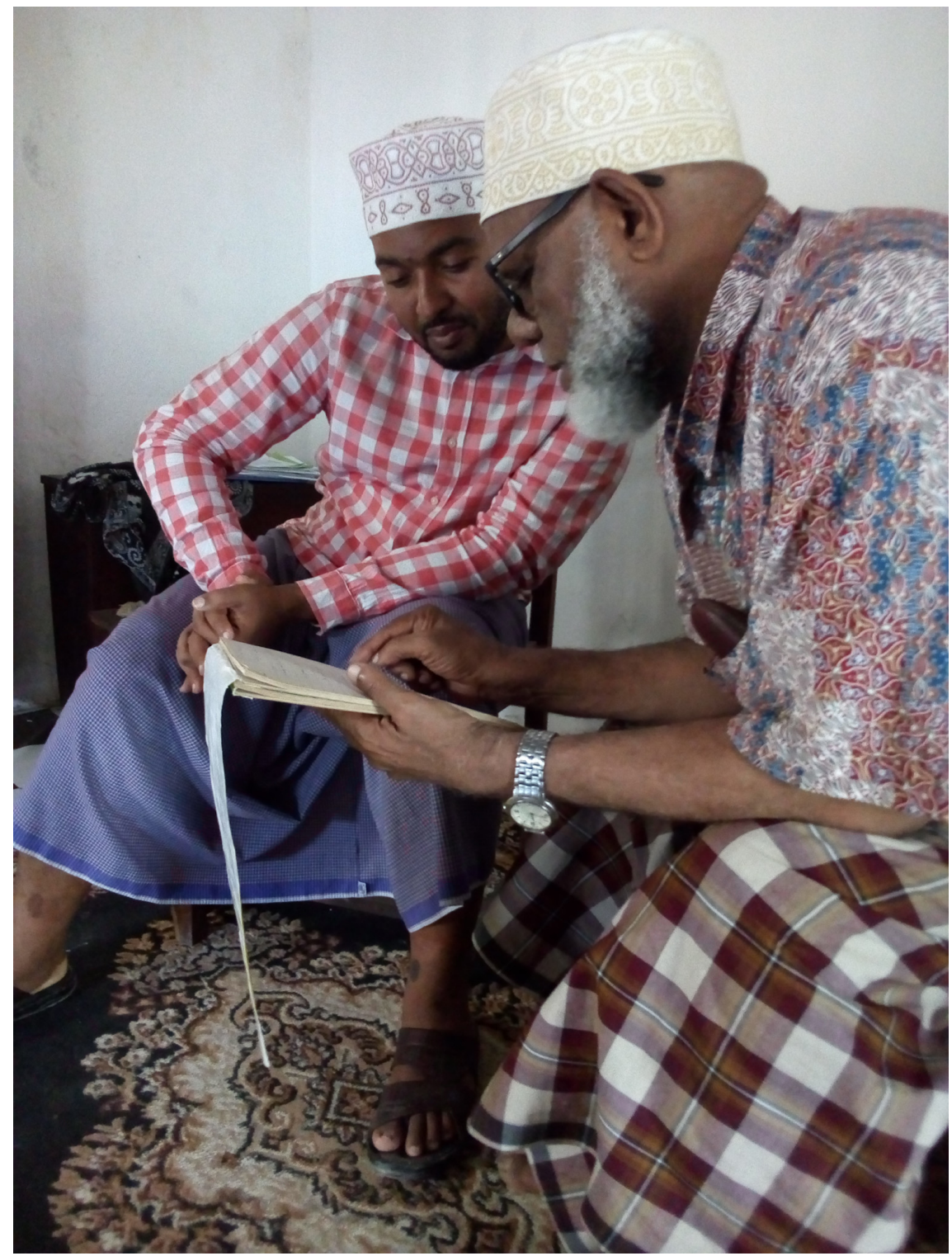

FIGURE 1 Mahmoud Mau and Bwana Fakruddin re-reading an utendi poem before a sample demonstrantion of kutia sauti in my presence. In the picture, Ustadh Mau holds his kitabu and Bwana Fakruddin has already performed. Mau rereads some lines to Bwana Fakruddin to comment on his reading of some passages.

PHOTO TAKEN BY THE AUTHOR, MARCH 2018 
already experienced." ${ }^{65}$ Mahmoud Mau's remarks echo an observation made by Barber: "it is well known that coming together as spectators or auditors of collective cultural events can have the effect of making people aware of the things they share; of rousing them to collective action; and of furnishing the means for expressions of collective sentiment" (139).

The audience of the poems recorded on $\mathrm{CD}$, today as in the past, consists chiefly of women and children who listen to these recordings together in the living rooms of their households. This is indeed what Kresse reports about the recording of the Wasiya wa Mabanati voiced by el-Shatry:

I had heard this recording first, in passing, when walking through the narrow streets of Mombasa's Old Town, as it was emanating from one of the houses on the side; its memorable sound struck a profound if passing impression. I was to hear it again and get to know more about it when visiting the house of a Swahili friend for dinner. He asked me to join in to listen to the poem and to participate in the conversation about it in which some family members and friends in his living room were just engaged. The sound came from an old cassette recorder in the corner, placed on a small table. A small group of women and children and, next to them, two men, were sitting on the floor around it, listening.

47

That poem, recorded on a tape whose sound emanated from a tape recorder, thus became a force that created a social experience, since, as Eisenberg too observes, "The singing voice can serve as a powerful technology of public reflexivity" (337).

Once the singer records his or her delivery of the poem, a relationship between the kitabu ("book") sent by the poet to the singer is realized. In Lamu, when Bwana Fakruddin had to record the Ramani ya Maisha ya Ndowa ("Map for Married Life") by Ustadh Mahmoud Mau and received the kitabu from the poet, he first undertook a sort of interior self-dictation of the poem-silently, in his own mind. ${ }^{66}$ Indeed, the one who gives voice to a text is, first and fore-

65 Wasiya wa mabanati husikitisha wengi na watu hupenda kusikiza kwa kuwa ni kiswa cha kusisimuwa nanimambo yamesha wapata baadhi yawatu (Ustadh Mahmoud Mau, October 2017).

66 In philology, to explain the presence of errors in transmitted texts, the self-dictation or interior pronunciation of a text is considered one of the four stages that take place while copying: visual perception of the letters, memorization, self-dictation and reproduction (Isella and Stussi 86). 
most, a reader who converts written words to sound. In his intimate encounter with the poem, Bwana Fakhruddin had first to face the challenges of the text itself - its language, the proper pronunciation of certain dialectal words, the content of the poem and the kind of voice and melody he should use: where and how should he mark the end of a stanza through his voice's crescendo and decrescendo? Should he imbue the length of the poem with a melody that makes people happy, sad or just not bored? These general questions lead to an inevitable-and more or less pervasive-reperformance of the text. As Fakhruddin recalls, the initial tests for recording "Ramani" in 2002 took place in the fields, far from the chaos of Lamu town. Since CD s had not yet come out at that time, the cassettes available to him were either 60 minutes or 90 minutes in duration. This meant that he had to adapt the tempo of his voice to the duration of the tape. Respecting that limit ensured that he could avoid using two cassettes, which would have cost more for the owner of the studio handling the recording. Once he was confident in his first test, he would then have also shared his first draft with the poet Mahmoud Mau and check if the composer was satisfied with it. Only then would the official recording in the studio begin, and after that, the poetry is officially put on the market and at the disposal of everyone.

The moment a poet such as Mahmoud Mau selects and contacts a reciter for his poem, a symbolic power making him the patron is somehow enacted. As a matter of fact, the composer/patron does not pay the singer for the "service" he is asking for, and - as I assume - a singer can hardly refuse to carry out this job due to certain rules of politeness and respect. Although, as Mahmoud Mau says, he does not earn anything from the recording activity, he has the power to choose whom he wants, to decide on one singer or another, and to say whether he is happy with the recorded version before it is officially released for sale on CD from the small local stalls. 67

However, there are also cases in which the singer allows himself to rearrange and adapt things. As the singer Kadara himself has said, for any performer who wishes (or is invited by a poet) to give voice to a text, it's undoubtedly important to know the verse form and to use a voice kwa maana ("which has a meaning"). The phrase kutia sauti kwa maana precisely encapsulates how

67 It goes beyond the scope of this paper to delve into an in-depth analysis on the commercialization of poetic performance nowadays. Yet, as Kaschula also concedes, "the commercialization of oral arts requires further research" (59). As for the West African context, it seems in fact that poets hardly receive gifts or remunerations, "but rather royalties from books published containing orally performed transcribed poetry, or from the sale of records, tapes and digital cassettes" (59). 
intervention shapes and transforms the texts to be recorded. The poet looks for "a meaningful voice," that is, a voice that suits the text, its structure and content. However, in giving a "meaningful voice" to a text written by someone else, the singer implicitly allows himself the freedom to sometimes rework the text, intentionally or otherwise. He may for instance change words, though respecting the syllables and rhyme pattern. ${ }^{68}$ By animating the text with his voice, he is making the written composition his own text. The result is that the sung version is different from the original composed by the poet, and indeed it is ascribed to a new name, no longer that of the composer but of the one who has sung it. Still, the names of the author (mtungaji) and singer (msomaji) are both announced at the start of the recording, before the poem begins. This opening section, commonly also voiced by the "singer," also announces the name and whereabouts of the recording studio and the local shop selling the recording. ${ }^{69}$

\subsection{Kutoa kwa moyo, "Recitation by Heart"}

A further and final striking performance practice comes from Pate, and is demonstrated by Bi Ridhai Sufiani, who owes her poetic talent to her grandmother. Besides Walter Ong, Richard Schechner and Willa Appel also consider imitation as the only means through which knowledge can be transferred, namely by the activity of recalling and/or imitating. Schechner and Appel refer to the transmission of performance knowledge in Africa as conducted in an "informal manner, beginning in very early childhood"; as part of this, "mothers move the arms of their infants in time with the drums", ${ }^{70}$ Bi Ridhai learned poetic craft by listening to her grandmother and the way she used to stitch words and thoughts together; in other words, Bi Ridhai did not learn, as Ong puts it, 'by study in a strict sense' (8). She did not receive a standard school edu-

68 Abdallah el-Shatry, for instance, in his recording of the Wasiya, changes the line reading Amu nitakuya ("to Lamu I will come") in stz. 38 to mimi nitakuya ("I will come"). Replacing mimi with Amu does not affect the total of eight syllables contained in that line, but does slightly modify the meaning of the line. The editing process that is thus undertaken by the new reader during the recording has also affected the Utendi wa Yusuf, ascribed to Ustadh Said Karama and later recorded by Kadara: while the "original" version reads kisa hicho maarufu, "this is an important story" (Karama 3), the recorded version recites nina kisa maarufu, "I have an important story".

69 For the CD s that I obtained from Mbwana Radio Service in Mombasa, the CD cover specifies the shopkeeper's copyright: haki zote zimeifadhiwa na Mbwana Radio Services, "all rights are reserved by Mbwana Radio Services". See also the citation of the author and reader of the "Wasiya" chanted by el-Shatry, available on SoundCloud: https://soundcloud .com/search?q=Wasiya\%2owa\%2omabanati.

70 Richard Schechner and Willa Appel. By means of performance: Intercultural studies of theatre and rituals (Cambridge: Cambridge University Press, 199o): 6. 
cation, but she has learned by apprenticeship, by listening and repeating what she heard. The performance practice through which Bi Ridhai has brought the sound of traditional utendi compositions to the world deserves attention, since it sheds light on a different dimension of poetic appropriation. She was not requested by anyone to perform the readings of specific poems, nor does she do it to sell her voice and talent. Her recordings of tendi-such as the Utendi wa Mwana Kupona ("The Poem of Mwana Kupona"), Utendi wa Ngamia na Paa ("The Poem of the Camel and the Gazelle"), Kisa cha Mtume Musa ("The Story of the Prophet Moses") and Kozi na Ndiwa ("The Story of the Falcon and the Dove")-were not meant to be released on CD or put for sale in local shops. She knows the poems by heart ( $k$ wa moyo) to the extent that she does not even need to have a kitabu at her side when she records them. In this respect, she is like her grandmother, who recited poems without any books, only knowing them by heart (kutoa kwa moyo). ${ }^{71}$

Furthermore, Bi Ridhai Sufiani's recordings have never been sold on CD; she just uses her mobile phone to make "private" recordings. As she says, she reads and gives voice to texts for her own enjoyment as well as training and refreshing her memory, and would not be capable of following the whole process that an official recording would require. Thus her recorded voice will not be released on CD s sold at local kiosks, the so-called "new stores of poetry" of today. In fact, her own "store" of poetry is kept alive through her memorization and whatever the limited memory of a mobile phone is able to store. Since, as Ong aptly puts it, "you know what you can recall" (33), what can the talented reciter from Pate recall and know by heart? Bi Ridhai reads and knows the traditional Swahili poems famously composed in nineteenth-century Lamu, such as Kisa cha Mtume Musa na Kozi na Ndiwa, ("The Poem of the Prophet Musa, the Falcon and the Dove") Utendiwa Mwana Kupona ("The Poem of Mwana Kupona"), Utendi wa Sayyidna Ali ("The Poem of Our Lord Ali") and, partially, the Utendi wa Mwana Aisha ("The Poem of Aisha"). As stated above, she knows and performs these poems for her own pleasure, but also as a way to ask for a reward from God. For instance, it is said that storing the Kisa cha Mtume Musa na Kozi na Ndiwa in the household will bring rewards from God in life and the afterlife. ${ }^{72}$ Therefore, the symbolic way through which Bi Ridhai keeps the poem

$71 \quad$ Nyanya hakua nakitabu alikua akitoa kwa moyo (Bi Ridhai, personal communication, September 2018).

72 This poem, also known as "Hadithi ya Kozi na Ndiwa" ("The Story of the Dove and the Goshawk"), is catalogued in different collections at soAs: MS 45022c (Allen Collection); MS 45022c (Taylor Papers); MS 38oo66d (Knappert Collection); and MS 53497e (Hichens Collection), together with a microfilm from the Allen Collection. The poem was published by Ernst Dammann in 1936 . 
alive in her dwelling is by reading it aloud and making it reverberate within the walls of her household and much beyond them. By doing this, Bi Ridhai is also ensuring that the abiding presence of a traditional Swahili Islamic poemhanded down in manuscript form and whose authorship has been extensively discussed-is still acknowledged and powerful..$^{73}$

I found Bi Ridhai's example of interiorizing poetry quite remarkable. The precise aesthetic experience of this intimate practice concerns the poet herself and her audience - the latter, however, still an imagined audience on the other side of the smartphone through which the master poetess recalls by heart, gives voice to, records and revives the poetry belonging to her ancestors.

\section{Conclusions: Toward New Poetry Storage Devices}

Each of the performance practices and artists I have focused on in this paper serves to illustrate new changes in the media of conveying, sharing, and memorizing poetry. The nitungiye nami, the poem "on behalf of" someone else, composed with a specific prosodic pattern, and committed to paper, both exists and does not exist, belongs and does not belong to anyone. We have seen how much its belonging fluctuates between the several artists/patrons who are all engaged with it on different levels: the composer, the customer-who plays a co-authorial role in suggesting what to say-and the recipient. In order to reach the listening community, it needs to be attractively performed in well-crafted verses.

The gesture of "sending a book" (kutuma kitabu) also constitutes a crucial moment in the history of a composition, in that the author authorizes it to be shared by a singer's giving voice to it. Giving voice (kutia sauti, maadhi and kutia sauti kwa maana) entails all the performance practices through which a recorded text is voiced as well as interpreted by choosing a fitting melody, selling and sharing it among the people. The voice imbues the texts-be they

73 On the authorship of this poem, see the following from the soAs item record in the Hichens Collection: "According to Abou Egl (unpubl. 1983), this story was translated from the Arabic by Kijumwa who gave it to Hichens in 1933. According to the manuscript, Kijumwa received the manuscript, in Arabic, from a woman in Lamu. The same poem was also given to E. Dammann who published it in 1938. In the Allen collection, this same poem is entitled "Hadithi ya Mtumi Musa." For further details on authorship, the soAS item record in Taylor Papers says: "... The author, named Muhammed" (without any further indication of his identity, letting us assume that he could be Muhamadi Kijuma), placing some doubt on whether Muhamadi Kijuma was the author or just the one who copied the manuscript. 


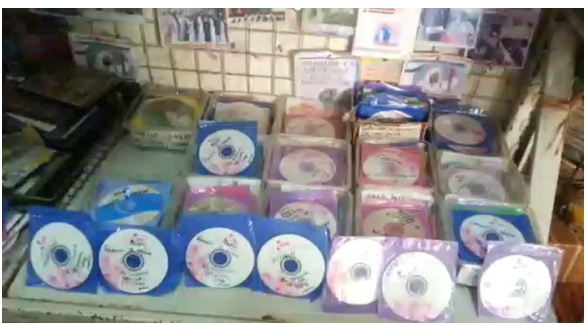

FIGURE 2

A view of the CD s available at al-Hussein Original Shop and Handicrafts, Mkomani area, Lamu COURTESY OF MAHMOUD MAU, OCTOBER 2017

traditional tendi or contemporary mashairi - with a performed presence, and thus they resonate not only within the community but also, first and foremost, in the poet's own heart and mind. If the textual composition did not undergo such a change of form - from written to vocal — it would remain just a stack of paper or unbound manuscript sheets, kept on the shelves or cupboards of the author's house.

Although money does play a role in the market of CD s for sale, what matters in composing and re-performing is the symbolic recognition and reward. The reward resides in the hope - or better, prayer $(d u a)$ — that that message or story might touch the recipients or make them think. This is valid for love messages written on commission; long, admonitory tendi; and poems for wedding celebrations just as well as for political purposes. ${ }^{74}$

In conclusion, having discussed Bi Ridhai's intimate way of recalling poems by heart has allowed us to show the "heterogeneity of speech genres" 75 in the art of composing poetry. Verbal artistry can be enacted differently and on different levels, related to each other by means of re-mediations: while there is a demand for poets to turn mere thoughts into good poems, singers are also needed to meaningfully voice them aloud, local shops to sell them, and households, audio recorders, and mobile phones to store them and allow them to circulate and reverberate within and around us.

74 It is worth quoting what Ibrahim Noor Shariff has argued in this respect: "Today, no Swahili politician running for office in the northern Kenya coast can hope to win without the backing of the 'Ulamaa' (religious scholars), especially the Sayyids (descendants of Prophet Muhammad), and the poets. The most important part of the campaign is conducted not on platforms in mass rallies where the candidate speaks. It is the poets, with their emotionally charged verses, usually in the utenzi form, that make the difference in a politican's success. These tenzi are recorded on tape and copied in large numbers for the listening pleasure of the electorate" (Shariff 54 ).

75 Michael Bakhtin. Speech Genres and Other Late Essays. Translated by Vern W. McGee. Edited by Caryl Emerson and Michael Holquist (Austin: University of Texas Press, 1986): 6 . 


\section{Works Cited}

Abdulaziz, Mohammed. Muyaka: 19th Century Swahili Popular Poetry (Nairobi: Kenya Literature Bureau, 1979).

Al-Faruqi, Lois I. "Music, Musicians and Muslim Law," Asian Music 17.1 (1985): 13-36.

Allen, John, W.T. (ed.). Tendi: Six Examples of a Swahili Classical Verse Form with Translations \& Notes (New York: Africana Pub. Corp., 1971).

Allen, John, W.T. The Swahili and Arabic Manuscripts and Tapes (Leiden: E.J. Brill, 1970).

Amidu, Assibi A. Kimwondo: A Kiswahili electoral contest (Vienna: Afro-Pub, 199o).

Andrzejewski, B.W. "The poem as message: Verbatim memorization in Somali poetry," Journal of African Cultural Studies, 23.1 (June 2011): 27-36.

Appadurai, Arjun. Social Life of Things: Commodities in Cultural Perspective (West Nyack: Cambridge University Press, 1986).

Banti, Giorgio and Francesco Giannattasio. "Music and Metre in Somali Poetry," African Languages and Cultures, Supplement (January 1996): 83-127.

Barthes, Roland. Image-Music-Text (Great Britain: Fontana Press, 1977).

Bourdieu, Pierre. "Les conditions sociales de la circulation internationale des idées," Actes de la recherche en sciences sociales 145.12 (2002): 3-8. Persee, DoI: 10.3406/arss .2002.2793.

Barber, Karin. The Anthropology of Texts, Persons and Publics: Oral and Written Culture in Africa and Beyond (Cambridge: Cambridge Univ. Press, 2007).

Bakthin, Michael. Speech Genres and Other Late Essays. Translated by Vern W. McGee. Edited by Caryl Emerson and Michael Holquist (Austin: University of Texas Press, 1986).

Dammann, Ernst. Dichtungen in der Lamu-Mundart des Suaheli (Hamburg: Friederichsen, De Gruyter, 1940).

Deeb, Lara and Mona Harb. "Sanctioned Pleasures: Youth, Piety and Leisure in Beirut," Middle East Report 245 (2007): 12-19.

Diop, Samba The Oral History and Literature of the Wolof People of Waalo, Northern Senegal. (New York: The Edwin Mellen Press, 1995).

During, Jean. "Hearing and Understanding In Islamic Gnosis," The World of Music 3.2 (1997): 127-137.

Eisenberg, Andrew J. "The Swahili Art of Indian Taarab: A Poetics of Vocality and Ethnicity on the Kenyan Coast," Comparative Studies of South Asia, Africa and the Middle East 37.2 (2017): 336-354.

Eickelmann, Dale F. "Communication and control in publication and its discontents," in: New Media in the Muslim World: The emerging public sphere, ed. D.F. Eickelman and J.W. Anderson. (Bloomington Indiana: Indiana University Press, 2003: 33-44).

Feld S., Fox A., Porcello T., Samuels D. (eds.). "Vocal Anthropology: From the Music of 
Language to the Language of Song," in: A Companion to Linguistic Anthropology, ed. by Duranti Alessandro (Malden, MA: Blackwell, 2007): 321-345.

Finnegan, Ruth. "How oral is oral literature?" Bulletin of the School of Oriental and African Studies 37.1 (1974): 52-64.

Finnegan, Ruth. Oral Literature in Africa (Cambridge: Open Book Publishers, 2012).

Goffman, Erwing. Forms of Talk (Philadelphia: Univ. Pa. Press, 1981).

Harries, Lyndon. "Strung Pearls. A Poem from the Swahili-Arabic Text," вsos, XV.1 (1953): 146-156.

Harries, Lyndon. Swahili Poetry (Oxford: Clarendon Press, 1962).

Hichens, William. Al-Inkishafi: The Soul's Awakening (London: Sheldon Press, 1939).

Hirschkind, Charles. The Ethical SoundScape: Cassette Sermons and Islamic Counterpublics (New York: Columbia University Press, 2006).

Honko, Lauri. Textualization of Oral Epics (Berlin, New York: de Gruyter, 200o).

Isella, Dante. Le carte mescolate vecchie e nuove (Torino: Piccola Biblioteca Einaudi, 2009).

Johnson, John William, Thomas A. Hale and Stephen Belcher (eds.). Oral Epics from Africa: Vibrant Voices from a Vast Continent (Bloomington \& Indianapolis: Indiana University Press, 1997).

Jones, Eldred and Eustace Palmer. Oral and Written Poetry in African Literature Today (London: James Currey and Trenton, NJ: Africa World Press, 1988).

Jouili, Jeanette S. and Annelies Moors. "Islamic Sounds and the Politics of Listening," Anthropological Quarterly 87.4 (Fall 2014): 977-988.

Karama, Said. Utenzi wa Nabii Yusuf (Mombasa: Haji Mohamed and Sons, 1994 [1968]).

Kaschula, Russel. African oral literature: Functions in contemporary context (Claremont: New Africa Books, 2001).

Kaschula, Russel. "Imbongi and griot: Toward a comparative analysis of oral poetics in Southern and West Africa," Journal of African Cultural Studies 12.1 (1999): 55-76, DOI: 10.1080/13696819908717840.

Kittler, Friedrich. Discourse Networks 1800/1900 (Stanford, CA: Stanford Univ. Press, 1990).

Knappert, Jan. "Swahili Literature in Arabic Script," in Manuscripts from the Middle East, 4, (1989): 74-84.

Knappert, Jan. Traditional Swahili Poetry: An Investigation into the Concepts of East African Islam as Reflected in the Utenzi Literature (Leiden: E.J. Brill, 1967).

Kresse, Kai. "Enduring Relevance Samples of oral poetry on the Swahili coast," Wasafiri 26.2 (2011): 46-49.

Kresse, Kai. Philosophising in Mombasa: Knowledge, Islam and Intellectual Practice on the Swahili Coast. (Edinburgh: Edinburgh Univ. Press, 2007).

Larkin, Brian. "Techniques of Inattention: The Mediality of Loudspeakers in Nigeria," Anthropological Quarterly 87.4 (Fall 2014): 989-1015. 
Merolla, Daniela, Jan Jansen and Kamal Naït-Zerrad. Multimedia research and documentation of oral genres in Africa: The step forward (Munich [etc.]: Lit Verlag, 2012).

Miehe, Gudrun and Clarissa Vierke. Muhamadi Kijuma. Texts from the Dammann Papers and Other Collections (Köln: Rüdiger Köppe Verlag, 2010).

Okpewho, Isidore. The Epic in Africa: Towards a Poetics of the Oral Performance (New York: Columbia University Press, 1979).

Omar, Yahya Ali and Peter J. Frankl. "A historical review of the Arabic rendering of Swahili together with proposals for the development of a Swahili writing system in Arabic script (based on the Swahili of Mombasa)," Journal of the Royal Asiatic Society 7.1 (1997): 55-71.

Ong, Walter. Orality and Literacy: The technologizing of the world (London: Routledge, 2002).

Orwin, Martin. “Somali Poetry," Greene, R., Cushman, S., Cavanagh, C., Ramazani, J., Rouzer, P. The Princeton Encyclopedia of Poetry and Poetics Princeton University Press (2012): 1313-1314.

Piłaszewicz, Stanisław. “The rise of written literatures in African languages," in: Andrzejewski, B.W., Piłaszewicz, S., Tyloch, W., Literatures in African languages: theoretical issues and sample surveys (Cambridge: Cambridge University Press et al., 1985): 4970.

Raia, Annachiara. "A Network of Copies: Transmission and Textual Variants of the Utendi wa Yusuf Manuscript Traditions from the J.W.T. Allen Collection (Dar es Salaam)," in One Text-Many Forms. A Comparative View on the Variability of Swahili Manuscripts, ed. Ridder Samsom and Clarissa Vierke. (Special Issue of Manuscript Cultures 12, forthcoming).

Schechner, Richard and Willa Appel. By means of performance: Intercultural studies of theatre and rituals (Cambridge: Cambridge University Press, 1990).

Shariff, Ibrahim Noor. "Islam and Secularity in Swahili Literature: An Overview," in Studies in African literature / New series. Faces of Islam in African literature, ed. Harrow, K.W. (Portsmouth, NH: Heinemann, 1991): 37-57.

Shariff, Ibrahim Noor. Tungo zetu: Msingi wa Mashairi na Tungo nyinginezo (Trenton, NJ: The Red Sea Press, 1988).

Stussi, Alfredo. Introduzione agli studi di filologia italiana (Bologna: Il Mulino, 2011). Vail, Leroy and Landeg White. Power and the Praise Poem. Southern African Voices in History (London: James Currey, 1991).

Vianello, Alessandra (ed.). 'Stringing Coral Beads': The Religious Poetry of Brava (c. 189o1975) (Leiden: Brill, 2018).

Vierke, Clarissa. “Akhipatia kalamu. Writing Swahili Poetry in Arabic Script," in Michael Mumin and Kees Versteegh (eds.): Arabic Script in Africa: Studies on the Usage of a Writing System (Leiden: Brill, 2014). 
Vierke, Clarissa. On the Poetics of the Utendi: A Critical Edition of the Nineteenth-Century Swahili Poem "Utendi wa Haudaji” Together with a Stylistic Analysis (Zürich: LIT, 2011).

Vierke, Clarissa. "'What Is There In My Speaking': Re-Explorations of Language in Abdilatif Abdalla's Anthology of Prison Poetry, Sauti Ya Dhiki," RAL 488.1 (2017):135157.

Werner, Alice. "Swahili Poetry," Bsos 1 (1917-1920): 113-127.

\section{Short List of CD Available in Mombasa and Lamu}

Utenzi wa Kifo cha Nabii Muhammad - Mbwana Radio Service, Mombasa

Utenzi wa Kikuba -Mbwana Radio Service, Mombasa

Utenzi *ya Haki *ya Watoto-Mbwana Radio Service, Mombasa

Utenzi wa Mtu ni Utu-Mbwana Radio Service, Mombasa

Utenzi wa Mabanati-Mbwana Radio Service, Mombasa

Utenzi wa Nana Nafisa - al-Hussein Original Shop, Lamu

Utenzi wa Nabii Ayyub — al-Hussein Original Shop, Lamu

Wasiya wa Mabanati-Mbwana Radio Service, Mombasa

Ramaniya Ndowa (Mke) - al-Hussein Original Shop, Lamu

Ramaniya Ndowa (Mume) —al-Hussein Original Shop, Lamu

Uzinduzi-al-Hussein Original Shop, Lamu

Mwangaza - al-Hussein Original Shop, Lamu

Haki za Watoto - al-Hussein Original Shop, Lamu

Bhalo \& Indian, 48 songs-al-Hussein Original Shop, Lamu

Bhalo, 355 songs - al-Hussein Original Shop, Lamu 